\title{
Comparison of a Nucleosidic vs Non-Nucleosidic Postsynthetic "Click" Modification of DNA with Base-Labile Fluorescent Probes
}

\author{
Sina Berndl,${ }^{\dagger}$ Nadine Herzig, ${ }^{\dagger}$ Péter Kele,${ }^{\ddagger}$ Daniel Lachmann, ${ }^{\dagger}$ Xiaohua Li,${ }^{\ddagger}$ Otto S. Wolfbeis,${ }^{\ddagger}$ and \\ Hans-Achim Wagenknecht*,
}

Institute of Organic Chemistry, University of Regensburg, D-93040 Regensburg, Germany and Institute of Analytical Chemistry, Chemo- and Biosensors, University of Regensburg, D-93040 Regensburg, Germany. Received November 7, 2008;

Revised Manuscript Received January 8, 2009

\begin{abstract}
The azides 1 and 2 bearing a phenoxazinium and a coumarin fluorophore, respectively, were applied in postsynthetic "click"-type bioconjugation and coupled to oligonucleotides modified with alkyne groups using two alternative approaches: (i) as a nucleotide modification at the $2^{\prime}$-position of uridine and (ii) as a nucleotide substitution using $(S)-(-)$-3-amino-1,2-propanediol as an acyclic linker between the phosphodiester bridges. The corresponding alkynylated phosporamidites 3 and $\mathbf{6}$ were used as DNA building blocks for the preparation of alkyne-bearing DNA duplexes. The base pairs adjacent to the site of modification and the base opposite to it were varied in the DNA sequences. The modified duplexes were investigated by UV/vis absorption spectroscopy (including melting temperatures) and fluorescence spectroscopy in order to study the different optical properties of the two chromophores and to evaluate their potential for bioanalytical applications. The sequence-selective fluorescence quenching of phenoxazinium 1 differs only slightly and does not depend on the type of modification, meaning whether it has been attached to the 2 '-position of uridine or as DNA base surrogate using the acyclic glycol linker. The $2^{\prime}$-chromophore-modified uridine still recognizes adenine as the counterbase, and the duplexes exhibit a sufficient thermal stability that is comparable to that of unmodified duplexes. Thus, the application of the $2^{\prime}$ modification site of uridine is preferred in comparison to glycol-assisted DNA base surrogates. Accordingly, the coumarin dye azide 2 was attached only to the $2^{\prime}$-position of uridine. The significant Stokes shift of $\sim 100 \mathrm{~nm}$ and the good quantum yields make the coumarin chromophore a powerful fluorescent label for nucleic acids.
\end{abstract}

\section{INTRODUCTION}

Bioanalytical methods based on nucleic acids often require the use of bright DNA labels for fluorescence readout $(1-12)$. The standard phosphoramidite DNA building block strategy enables a large variety of organic fluorophores to be routinely incorporated at specific positions within the oligonucleotide. Alternatively, postsynthetic labeling with fluorophores can be performed via amide bond formation to internal, 3'- and 5'terminal modifiers that are commercially or synthetically available as phosphoramidites (13). In recent years, the "click" ligation strategy has become an important alternative. Huisgen originally described the $[2+3]$-cycloaddition between alkynes and azides yielding 1,2,3-triazoles (14). The utility of this reaction as a bioligation method has grown incredibly after Sharpless had reported that the addition of $\mathrm{Cu}(\mathrm{I})$ led to a significant increase in the reaction rate and in regioselectivity (15). This type of "click" chemistry has been widely used as a bioconjugation method $(16-27)$ due to the mild reaction conditions and the bioorthogonal functional groups meaning that both alkynes and azides typically are not present in biopolymers (28-31). Using the "click" chemistry, up to six modifications have been incoporated simultaneously (32) and up to three modifications consecutively into oligonucleotides (33). Highly modified DNA can be prepared by a combination of PCR with triphosphates bearing alkynes (34).

\footnotetext{
* Corresponding author. E-mail: achim.wagenknecht@ chemie.uni-regensburg.de, Fax: 499419434802.

${ }^{\dagger}$ Institute of Organic Chemistry, University of Regensburg, D-93040 Regensburg, Germany.

* Institute of Analytical Chemistry, Chemo- and Biosensors, University of Regensburg, D-93040 Regensburg, Germany.
}

It became clear that "click" chemistry is predestined for the application as a postsynthetic ligation for nucleic acids in order to avoid the time-consuming synthesis of phosphoramidites as DNA building blocks $(20,21)$. This is especially important for a number of remarkable and brightly emitting fluorophores that are not compatible with the acidic, oxidative, or basic conditions of automated DNA phosphoramidite chemistry and DNA workup. For instance, phenoxazinium and coumarin dyes represent brightly emitting organic fluorophores that are not stable under the typically strong basic conditions during DNA cleavage and deprotection. Hence, these labels cannot be incorporated into oligonucleotides using the conventional phosphoramidite chemistry.

Herein, we present the application of "click" chemistry for postsynthetic attachment of the fluorescent azides $N$-(5-(3azidopropylamino)-9H-benzo[ $a]$ phenoxazin-9-ylidene)- $N$-methylmethanaminium (1) (35) and (E)-1-(3-azidopropyl)-4-(2-(7(diethylamino)-2-oxo-2 $H$-chromen-3-yl)vinyl)pyridinium $(2)(35,36)$ (Scheme 1) as representatives of a phenoxazinium and a coumarin dye, respectively. They were coupled to oligonucleotides that are modified with alkyne groups using two alternative structural approaches: (i) as a nucleotide modification at the $2^{\prime}$-position of uridine and (ii) as a nucleotide substitution using $(S)$-(-)-3-amino-1,2-propanediol as an acyclic linker between the phosphodiester bridges. The resulting duplexes were investigated by optical spectroscopy in order to study the different stacking situations of the chromophores and to evaluate their potential in oligonucleotide-based assays.

\section{EXPERIMENTAL PROCEDURES}

Materials and Methods. Chemicals were purchased from Aldrich, Alfa Aesar, and Merck. Unmodified oligonucleotides 
Scheme 1. Building Blocks for the Postsynthetic "Click" Chemistry with Oligonucleotides ${ }^{a}$

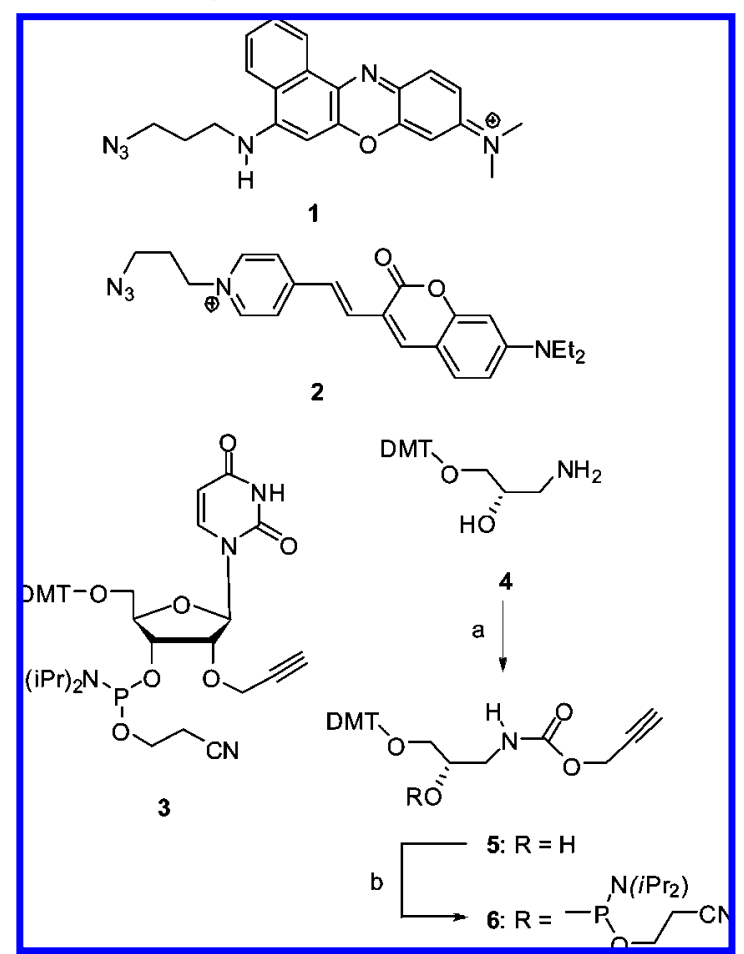

${ }^{a}$ Azides 1, 2 and alkyne phosphoramidites 3, 4: (a) 2-propyn-1-ol, $1,1^{\prime}$-carbonyldiimidazole, DMF, r.t., $27 \mathrm{~h} ; 76 \%$; (b) 2-cyanoethyl- $N, N$ diisopropylchlorophosphoramidite, $\mathrm{EtN}(i \mathrm{Pr})_{2}, \mathrm{CH}_{2} \mathrm{Cl}_{2}$, r.t., 3 h.

were purchased from Metabion. TLC was performed on Fluka silica gel $60 \mathrm{~F}_{254}$ coated aluminum foil. Flash chromatography was carried out with silica gel 60 from Aldrich $(60-43 \mu \mathrm{m})$. Spectroscopic measurements were recorded in sodium phosphate buffer solution $(10 \mathrm{mM})$ using quartz glass cuvettes $(10 \mathrm{~mm})$. ESI mass spectra were acquired in the central analytical facility of the faculty on a ThermoQuest Finnigan TSQ 7000 in negative and positive ionization mode. NMR spectra were recorded on a Bruker Avance 300 spectrometer in deuterated solvents that had been dried over basic alumina. Chemical shifts are given in ppm relative to TMS. Absorption spectra and the melting temperatures $\left(2.5 \mu \mathrm{M}\right.$ DNA, $250 \mathrm{mM} \mathrm{NaCl}, 10-90{ }^{\circ} \mathrm{C}, 0.7^{\circ} \mathrm{C} /$ min, step width $0.5^{\circ} \mathrm{C}$ ) were recorded on a Varian Cary 100 spectrometer equipped with a $6 \times 6$ cell changer unit. Fluorescence spectra were acquired on a Jobin-Yvon Fluoromax 3 fluorimeter in spectral steps of $1 \mathrm{~nm}$ and an integration time of $0.2 \mathrm{~s}$. All spectra were recorded with an excitation and emission bandpass of $2 \mathrm{~nm}$ and are corrected for Raman emission from the buffer solution.

Synthesis of 5. 2-Propyn-1-ol (40 $\mu \mathrm{L}, 700 \mu \mathrm{mol})$ was dissolved in DMF (5 mL). 1,1'-carbonyldiimidazole $(114 \mathrm{mg}$, $700 \mu \mathrm{mol})$ was added and the solution was stirred at room temperature for $3 \mathrm{~h}$. (3-(4,4'-Dimethoxytrityl)-2-hydroxy-propylamine (4) $(268 \mathrm{mg}, 700 \mu \mathrm{mol})$ was added and the solution was stirred for another $24 \mathrm{~h}$ at room temperature and then evaporated to dryness. The crude product was purified by flash chromatography $\left(\mathrm{CH}_{2} \mathrm{Cl}_{2}, 0.1 \% \mathrm{NEt}_{3}\right)$ yielding a yellow solid (76\%). TLC $\left(\mathrm{CH}_{2} \mathrm{Cl}_{2} / \mathrm{MeOH} 100: 2\right) R_{\mathrm{f}}=0.3$. ${ }^{1} \mathrm{H}$ NMR $(300$ $\mathrm{MHz},\left[d_{6}\right]$-acetone): $\delta=7.51-7.48 \mathrm{ppm}(\mathrm{m}, 2 \mathrm{H}$, arom. DMT), 7.37-7.28 (m, 7H, arom. DMT), 6.89-6.86 (m, 4H, arom. DMT), $6.26(\mathrm{~m}, 1 \mathrm{H}, \mathrm{NH}), 4.64\left(\mathrm{~d}, J=2.47,2 \mathrm{H}, \mathrm{CH}_{2} \mathrm{CCH}\right)$, $4.17(\mathrm{~d}, J=5.21,1 \mathrm{H}, \mathrm{OH}), 3.92-3.86\left(\mathrm{~m}, 1 \mathrm{H}, \mathrm{CH}_{2} \mathrm{CHCH}_{2}\right)$, 3.79 (s, 6H, OMe), 3.45-3.37 (m, 1H, $\mathrm{CH}_{2} \mathrm{CHCH}_{2}$ ), 3.22-3.15 (m, $1 \mathrm{H}, \mathrm{CH}_{2} \mathrm{CHCH}_{2}$ ), 3.13-3.05 (m, 2H, $\left.\mathrm{CH}_{2} \mathrm{CHCH}_{2}\right), 2.98$ (t, $J=2.47,1 \mathrm{H}, \mathrm{CCH}) . \mathrm{MS}(\mathrm{FAB}): \mathrm{m} / \mathrm{z}(\%) 303.1$ (100)
$[D M T]^{+}, 475.5\left[\mathrm{MH}^{+}\right]$. HRMS (FAB): $\mathrm{M}^{+}$calcd for $\mathrm{C}_{28} \mathrm{H}_{30} \mathrm{NO}_{6}$ $\left[\mathrm{MH}^{+}\right]$: 476.2073. Found: 476.2085.

Synthesis of 6. Compound $5(350 \mathrm{mg}, 0.74 \mathrm{mmol})$ was dissolved under nitrogen in dry $\mathrm{CH}_{2} \mathrm{Cl}_{2}(5 \mathrm{~mL})$. Dry ethyldiisopropylamine $(380 \mu \mathrm{L}, 2.21 \mathrm{mmol})$ and 2-cyanoethyl- $N, N$ diisopropylchlorophosphoramidite $(181 \mu \mathrm{L}, 0.81 \mathrm{mmol})$ were added, and the solution was stirred for $3 \mathrm{~h}$ at r.t. The mixture was washed with freshly prepared sat. aqueous $\mathrm{NaHCO}_{3}$, dried over $\mathrm{Na}_{2} \mathrm{SO}_{4}$, and evaporated to dryness. The crude product was purified by flash chromatography $\left(\mathrm{CH}_{2} \mathrm{Cl}_{2} / \mathrm{MeOH} 100: 2,0.1 \%\right.$ ( $\left.\left.{ }^{\mathrm{P} r}\right)_{2} \mathrm{NEt}\right)$. The resulting yellow foam $(80 \%)$ was dissolved in dry $\mathrm{MeCN}(6.1 \mathrm{~mL})$ and applied directly for automated DNA synthesis. TLC $\left(\mathrm{CH}_{2} \mathrm{Cl}_{2} / \mathrm{MeOH} 100: 2\right): R_{\mathrm{f}}=0.6 .{ }^{1} \mathrm{H}$ NMR $(300$ $\left.\mathrm{MHz},\left[d_{6}\right]-\mathrm{C}_{3} \mathrm{D}_{6} \mathrm{O}\right): \delta=1.06-1.19(\mathrm{~m}, 12 \mathrm{H}, 4 \times \mathrm{Me}$ ('Prop)), $2.58\left(\mathrm{t}, J_{\mathrm{z}}=6.04,1 \mathrm{H}, \equiv \mathrm{H}\right), 2.76(\mathrm{~m}, 2 \mathrm{H}), 2.95(\mathrm{~m}, 1 \mathrm{H}), 3.07$ $(\mathrm{m}, 1 \mathrm{H}), 3.22(\mathrm{~m}, 1 \mathrm{H}), 3.36(\mathrm{~m}, 1 \mathrm{H}), 3.54(\mathrm{~m}, 1 \mathrm{H}), 3.61(\mathrm{~m}$, $2 \mathrm{H}), 3.85(\mathrm{~m}, 1 \mathrm{H}), 3.75(\mathrm{~s}, 6 \mathrm{H}, 2 \times \mathrm{OMe}), 4.10(\mathrm{~m}, 1 \mathrm{H}), 4.60$ $\left(\mathrm{dd}, J_{\mathrm{z}}=2.47, \mathrm{CH}_{2} \equiv\right), 6.20(\mathrm{~m}, 1 \mathrm{H}, \mathrm{NH}), 6.83-6.88(\mathrm{~m}, 4 \mathrm{H}$, arom.), 7.25-7.35 (m, 7H, arom.), 7.46-7.49 (m, 2H, arom.). ${ }^{31} \mathrm{P}$ NMR (121 MHz, $\left[d_{6}\right]$-acetone): $=150.6$.

Preparation of Modified Oligonucleotides. Oligonucleotides were prepared on an Expedite 8909 Synthesizer from Applied Biosystems (ABI) using standard phosphoramidite chemistry. Reagents and controlled pore glass (CPG) (1 $\mu \mathrm{mol})$ were purchased from ABI and Glen Research. The synthesis of DNA oligonucleotides modified with the acyclic linked acetylene was performed using a modified protocol. Activator solution $(0.45$ $\mathrm{M}$ tetrazole in acetonitrile) was pumped together with the building block $(0.15 \mathrm{M}$ in acetonitrile) through the CPG vial. The coupling time was extended to $61 \mathrm{~min}$ with an intervening step after 30.8 min for washing and refreshing the activator/ phosphoramidite solution in the CPG vial. The CPG vial was flushed with dry acetonitrile after coupling. Acetylene-modified uridine was introduced into DNA by using standard coupling conditions. The concentration of the building block was increased to $0.1 \mathrm{M}$. After preparation, the trityl-off oligonucleotides were cleaved from the resin and deprotected by treatment with conc. $\mathrm{NH}_{4} \mathrm{OH}$ at room temperature for $24 \mathrm{~h}$.

“Click" Ligation. The azides $\mathbf{1}$ (blue) and $\mathbf{2}$ (red) were synthesized according to the literature $(35,36)$. The azide 1 or $2(114 \mu \mathrm{L}, 10 \mathrm{mM}), \mathrm{Cu}(\mathrm{I})(17 \mu \mathrm{L}, 100 \mathrm{mM})$, TBTA $(34 \mu \mathrm{L}$, $100 \mathrm{mM}$ ), each in $\mathrm{DMSO} /{ }^{\circ} \mathrm{BuOH}=3: 1$, and sodium ascorbate (25 $\mu \mathrm{L}, 400 \mathrm{mM}$ ) in $\mathrm{H}_{2} \mathrm{O}$ was added to the oligonucleotide (1 $\mu \mathrm{mol})$. The reaction mixture was vortexed, shaken overnight at room temperature, and then evaporated to dryness using a speedvac. Sodium acetate $(100 \mu \mathrm{L}, 0.15 \mathrm{mmol})$ was added and the mixture stored for $1 \mathrm{~h}$ at room temperature. Ethanol $(1 \mathrm{~mL})$ was added and the mixture vortexed and frozen $\left(-20{ }^{\circ} \mathrm{C}\right)$ overnight. The suspension was centrifuged (13 $000 \mathrm{rpm}, 15 \mathrm{~min}$ ) and the supernatant removed. The pellet was washed twice with ethanol $(500 \mu \mathrm{L})$ and then dissolved in water $(500 \mu \mathrm{L})$. Prior to purification by HPLC, the DNA was desalted by NAP-5 column (GE Healthcare).

DNA Purification. The modified oligonucleotides were purified by HPLC on a semipreparative RP-C18 column (300 $\AA$, Supelco) using the following conditions: $\mathrm{A}=\mathrm{NH}_{4} \mathrm{OAc}$ buffer $(50 \mathrm{mM}), \mathrm{pH}=6.5 ; \mathrm{B}=$ acetonitrile; gradient $0-30 \% \mathrm{~B}$ over $50 \mathrm{~min}$, flow rate $2.5 \mathrm{~mL} / \mathrm{min}$, UV/vis detection at 260 and 641 $\mathrm{nm}$. The oligonucleotides were lyophilized and quantified by their absorbance in $10 \mathrm{mM}$ sodium phosphate buffer at $260 \mathrm{~nm}$ on a Varian Cary 100 spectrometer. Duplexes were formed by heating to $90{ }^{\circ} \mathrm{C}(15 \mathrm{~min})$ followed by slow cooling. MS (ESI): DNA1 calc. 5453, found $\mathrm{m} / \mathrm{z}=1092.1[\mathrm{M} / 5]^{5+}, 1364.8[\mathrm{M} / 4]^{4+}$, $1819.5[\mathrm{M} / 3]^{3+} ; \varepsilon(260 \mathrm{~nm})=159090\left[\mathrm{~mol} \mathrm{~L}^{-1} \mathrm{~cm}^{-1}\right]$. DNA2 calc. 5562, found $\mathrm{m} / \mathrm{z}=1390.0[\mathrm{M} / 4]^{4-}, 1853.8[\mathrm{M} / 3]^{3-} ; \varepsilon(260$ $\mathrm{nm})=181650\left[\mathrm{~mol} \mathrm{~L}^{-1} \mathrm{~cm}^{-1}\right]$; DNA3 calc. 5594 , found $\mathrm{m} / \mathrm{z}$ $=1397.9[\mathrm{M} / 4]^{4-}, 1864.4[\mathrm{M} / 3]^{3-} ; \varepsilon(260 \mathrm{~nm})=166270[\mathrm{~mol}$ 
$\mathrm{L}^{-1} \mathrm{~cm}^{-1}$; DNA5 calc. 5503, found $\mathrm{m} / \mathrm{z}=1833.9[\mathrm{M} / 3]^{3-} ; \varepsilon$ $(260 \mathrm{~nm})=164290\left[\mathrm{~mol} \mathrm{~L}^{-1} \mathrm{~cm}^{-1}\right]$; DNA6 calc. 5612, found $m / z=1402.3[\mathrm{M} / 4]^{4-}, 1869.9[\mathrm{M} / 3]^{3-} ; \varepsilon(260 \mathrm{~nm})=186850$ $\left[\mathrm{mol} \mathrm{L}{ }^{-1} \mathrm{~cm}^{-1}\right]$; DNA7 calc. 5644 , found $\mathrm{m} / \mathrm{z}=1410.3[\mathrm{M} / 4]^{4-}$, $1881.3[\mathrm{M} / 3]^{3-} ; \varepsilon(260 \mathrm{~nm})=171470\left[\mathrm{~mol} \mathrm{~L}^{-1} \mathrm{~cm}^{-1}\right]$.

\section{RESULTS}

"Click" Bioconjugations. The fluorophore azides 1 (blue) and 2 (red) were incorporated oligonucleotides bearing the alkyne group either as a nucleotide modification at the $2^{\prime}$-position of uridine or as a nucleotide substitution using $(S)-(-)$-3-amino-1,2-propanediol as an acyclic linker between the phosphodiester bridges. The first DNA building block, $5^{\prime}$-O-dimethoxytrityl- $N^{3}$-pivaloyloxymethyl2'-O-propargyluridine-3'-O-(2-cyanoethyl- $N, N$-diisopropylphosphoramidite (3), can be synthesized according to the literature procedure (37). In the second DNA building block, ethynyl (2S)3-(bis(4-methoxyphenyl)(phenyl)methoxy)-2-((2-cyanoethoxy)(diisopropylamino)phosphinooxy)propylcarbamate (6), the 2'-deoxyribofuranoside moiety was replaced by an acyclic linker. Similar glycol linkers have been used by others in order to prepare glycol nucleic acid (GNA) $(38,39)$, twisted intercalating nucleic acids (TINA) $(25,40)$, and alkyne-modified oligonucleotides for the "click" cycloaddition as a postsynthetic modification (33). We had previously used this structural approach for the incorporation of ethidium $(41,42)$, indole (43), perylene bismimide $(44,45)$, phenothiazine (46), and thiazole orange (47) into oligonucleotides via the corresponding phosphoramidites as DNA building blocks. In contrast to the latter examples, we have connected the glycol linker not directly to the propargyl group but via a carbamate function. This facilitates the synthesis of the corresponding DNA building block $\mathbf{6}$, since the protection of the $\mathrm{N}-\mathrm{H}$ group of the linker part is not necessary. The DMT-protected $(S)$-3-amino-1,2propanediol 4 as the precursor was synthesized according to the literature (41). The hydroxy function of commercially available 2-propyn-1-ol was converted into an activated ester by $1,1^{\prime}$ carbonyldiimidazole, and the subsequent nucleophilic acyl substitution with $\mathbf{4}$ gave the conjugate $\mathbf{5}$ in $\mathbf{7 6 \%}$ yield. The synthesis of the phosphoramidite $\mathbf{6}$ was accomplished by standard procedures.

The detritylated oligonucleotides were automatically synthesized at the $1 \mu \mathrm{mol}$ scale using the synthetic phosphoramidites $\mathbf{3}$ or $\mathbf{6}$ and coupled to the azides $\mathbf{1}$ or $\mathbf{2}$, respectively, in the presence of an excess of $\mathrm{Cu}(\mathrm{I})$, TBTA, and sodium ascorbate in a $\mathrm{DMSO} /{ }^{t} \mathrm{BuOH}(3: 1)$ solvent mixture at room temperature overnight. After lyophilization and ethanol precipitation, the modified single strands DNA1-DNA3 and DNA5-DNA7 were purified by semipreparative HPLC and finally desalted. All modified oligonucleotides were studied by UV/vis absorption and fluorescence spectroscopy (including quantum yields); the corresponding duplexes DNA1Y-DNA3Y and DNA5Y-DNA7Y additionally by measurement of the melting temperature $\left(T_{\mathrm{m}}\right)$. The unmodified duplexes DNA4Y and DNA8Y were used as references (Scheme 2).

Phenoxazinium-Modified DNA. The sequences of DNA1Y, DNA2Y, DNA5Y, and DNA6Y bear the blue phenoxazinium chromophore in three different structural variations (Scheme 2): (I) The chromophore was either connected to the $2^{\prime}$-position of uridine (DNA2Y and DNA6Y) or as a non-nucleosidic DNA base replacement (DNA1Y and DNA5Y). (II) The base pairs directly adjacent to the phenoxazinium modification site were varied (A-T in DNA1Y/DNA2Y or G-C in DNA5Y/DNA6Y). (III) The base opposite to the modification site was varied (Y $=\mathrm{A}, \mathrm{T}, \mathrm{C}$, or $\mathrm{G})$.

First, we measured the melting temperatures $\left(T_{\mathrm{m}}\right)$ of the phenoxazinium-modified duplexes at $260 \mathrm{~nm}$ (Tables 1 and 2) in order to study the influence of the phenoxazinium moiety on the duplex stability. The following major effects have been observed: (i) The phenoxazinium chromophore as a non-
Scheme 2. Sequences and Numbering of the Modified Duplexes DNA1Y-DNA8Y ${ }^{a}$

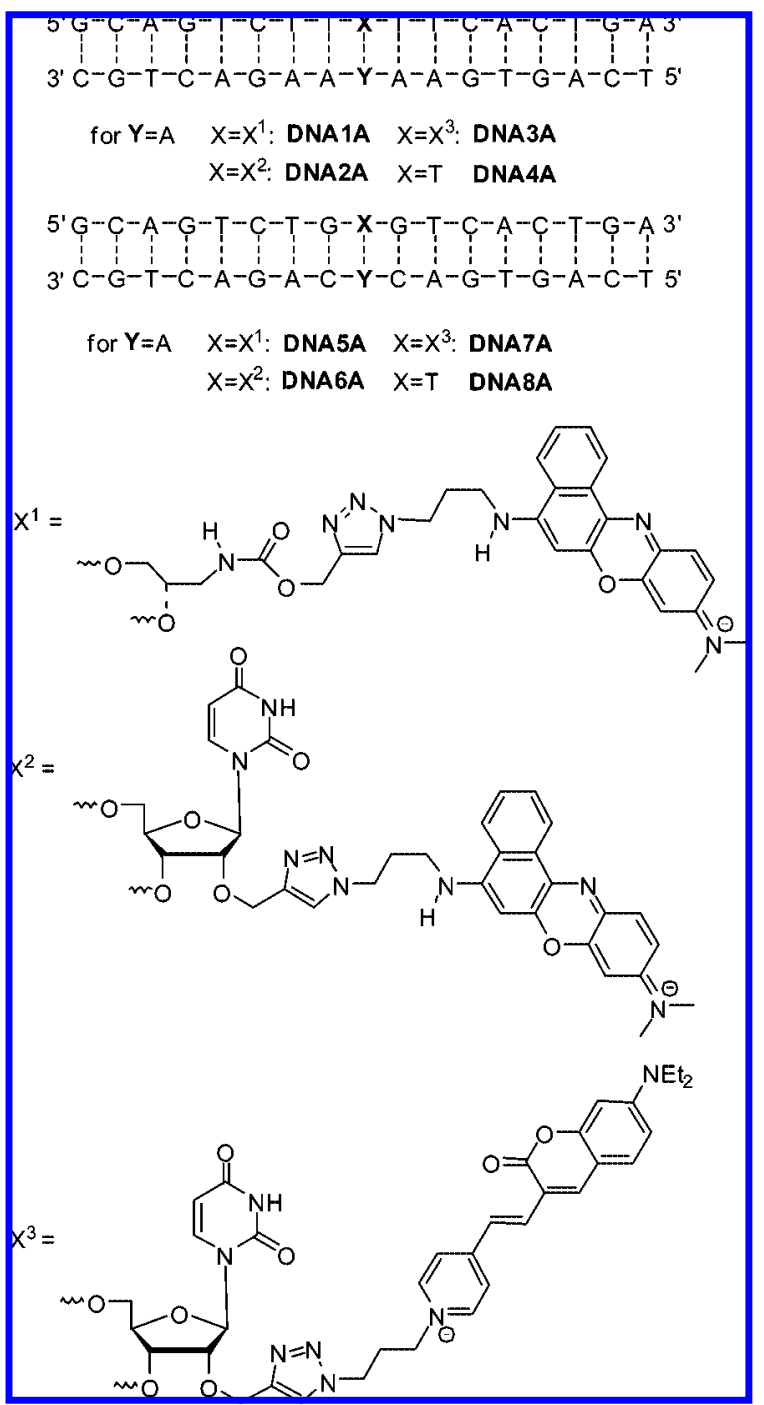

${ }^{a}$ Representatively shown for $\mathbf{Y}=\mathrm{A}$. For $\mathbf{Y}=\mathrm{T}, \mathrm{C}, \mathrm{G}$, structures are numbered accordingly (see Table 1 and Table 2).

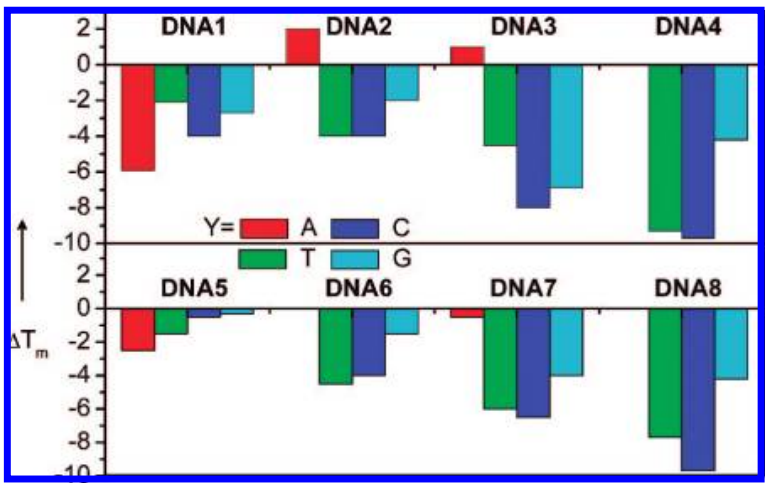

Figure 1. Melting temperature differences of duplexes DNA1-DNA4 in comparison to DNA4A as the reference and DNA5-DNA8 in comparison to DNA8A as the reference.

nucleosidic base surrogate in DNA1Y and DNA5Y does not exhibit any preferential base pairing with the counterstrand. (ii) In contrast, the phenoxazinium-modified uridine in DNA2Y and DNA6Y clearly prefers the adenine opposite to the modification site. (iii) Regardless of the type of modification and the sequential context, the "mismatched" modified duplexes DNA1Y, DNA2Y, DNA5Y, and DNA6Y $(Y=T, C, G)$ are 
Table 1. Quantum Yields $\left(\Theta_{\mathrm{F}}\right)$ and Melting Temperatures $\left(T_{\mathrm{m}}\right)$ of DNA1Y-DNA4Y

\begin{tabular}{llllll}
\hline & & $\mathrm{X}=\mathrm{X}^{1} / \mathrm{R}^{1}$ & $\mathrm{X}=\mathrm{X}^{2} / \mathrm{R}^{1}$ & $\mathrm{X}=\mathrm{X}^{2} / \mathrm{R}^{1}$ & \multicolumn{1}{c}{$\mathrm{X}=\mathrm{T}$} \\
\hline & & DNA1 (ss) & DNA2 $(\mathrm{ss})$ & DNA3 $(\mathrm{ss})$ & DNA4 $(\mathrm{ss})$ \\
$\mathrm{Y}=\mathrm{A}$ & $\Theta_{\mathrm{F}}$ & 0.159 & 0.176 & 0.283 & - \\
& & DNA1A & DNA2A & DNA3A & DNA4A \\
& $\Theta_{\mathrm{F}}$ & 0.151 & 0.122 & 0.317 & - \\
$\mathrm{Y}=\mathrm{T}$ & $T_{\mathrm{m}}\left({ }^{\circ} \mathrm{C}\right)$ & 56.6 & 64.5 & 63.5 & 62.5 \\
& & DNA1T & DNA2T & DNA3T & DNA4T \\
& $\Theta_{\mathrm{F}}$ & 0.188 & 0.147 & 0.346 & - \\
$\mathrm{Y}=\mathrm{C}$ & $T_{\mathrm{m}}\left({ }^{\circ} \mathrm{C}\right)$ & 60.4 & 58.5 & 58.0 & 53.2 \\
& & DNA1C & DNA2C & DNA3C & DNA4C \\
& $\Theta_{\mathrm{F}}$ & 0.221 & 0.163 & 0.305 & - \\
$\mathrm{Y}=\mathrm{G}$ & $\mathrm{T}_{\mathrm{m}}\left({ }^{\circ} \mathrm{C}\right)$ & 58.5 & 58.5 & 54.5 & 52.8 \\
& & DNA1G & DNA2G & DNA3G & DNA4G \\
& $\Theta_{\mathrm{F}}$ & 0.055 & 0.030 & 0.299 & - \\
& $T_{\mathrm{m}}\left({ }^{\circ} \mathrm{C}\right)$ & 59.8 & 60.5 & 55.6 & 55.0
\end{tabular}

Table 2. Quantum Yields $\left(\Theta_{\mathrm{F}}\right)$ and Melting Temperatures $\left(T_{\mathrm{m}}\right)$ of DNA5Y-DNA8Y

\begin{tabular}{llllll}
\hline & & $\mathrm{X}=\mathrm{X}^{1} / \mathrm{R}^{1}$ & $\mathrm{X}=\mathrm{X}^{2} / \mathrm{R}^{1}$ & $\mathrm{X}=\mathrm{X}^{2} / \mathrm{R}^{1}$ & \multicolumn{1}{c}{$\mathrm{X}=\mathrm{T}$} \\
\hline & & DNA5 $(\mathrm{ss})$ & DNA6 $(\mathrm{ss})$ & DNA7 $(\mathrm{ss})$ & DNA8 $(\mathrm{ss})$ \\
$\mathrm{Y}=\mathrm{A}$ & $\Theta_{\mathrm{F}}$ & 0.051 & 0.041 & 0.312 & - \\
& & DNA5A & DNA6A & DNA7A & DNA8A \\
& $\Theta_{\mathrm{F}}$ & 0.015 & 0.025 & 0.202 & - \\
$\mathrm{Y}=\mathrm{T}$ & $T_{\mathrm{m}}\left({ }^{\circ} \mathrm{C}\right)$ & 65.5 & 68.0 & 67.5 & 68.0 \\
& & DNA5T & DNA6T & DNA7T & DNA8T \\
& $\Theta_{\mathrm{F}}$ & 0.016 & 0.029 & 0.199 & - \\
$\mathrm{Y}=\mathrm{C}$ & $T_{\mathrm{m}}\left({ }^{\circ} \mathrm{C}\right)$ & 66.5 & 63.5 & 62.0 & 60.3 \\
& & DNA5C & DNA6C & DNA7C & DNA8C \\
& $\Theta_{\mathrm{F}}$ & 0.011 & 0.014 & 0.266 & - \\
$\mathrm{Y}=\mathrm{G}$ & $\mathrm{T}_{\mathrm{m}}\left({ }^{\circ} \mathrm{C}\right)$ & 67.5 & 64.0 & 61.5 & 58.3 \\
& & DNA5G & DNA6G & DNA7G & DNA8G \\
& $\Theta_{\mathrm{F}}$ & 0.009 & 0.018 & 0.255 & - \\
& $T_{\mathrm{m}}\left({ }^{\circ} \mathrm{C}\right)$ & 67.7 & 66.5 & 62.0 & 63.8
\end{tabular}

more stable compared to the corresponding unmodified mismatched duplexes DNA4Y and DNA8Y, respectively. This result indicates a stabilization of base mismatches by the stacking interactions with the phenoxazinium chromophore. The following additional effects can be drawn if the unmodified and matched DNA4A and DNA8A are regarded as the references (Figure 1): (iv) The replacement of the 2 '-deoxyribofuranoside by the acyclic glycol linker results in a decrease of thermal stability by $5.9{ }^{\circ} \mathrm{C}$ in DNA1A and $4.0{ }^{\circ} \mathrm{C}$ in DNA5A. (v) In contrast, the incorporation of the phenoxazinium chromophore as a nucleosidic 2'-modification yields duplexes of equal (DNA2A) or even by $2{ }^{\circ} \mathrm{C}$ higher thermal stability (DNA6A).

The UV/vis spectra of all modified single strands and all duplexes show the typical absorption of the blue chromophore with maxima in the small range between 652 and $661 \mathrm{~nm}$ (Supporting Information Figures S1, S2, S4, S5). The absorption properties do not reflect a systematic change of properties as a result of any of the three different structural variations I-III. In contrast, the fluorescence of the duplexes show the influence of the sequential neighborhood (Figure 2). The quantum yield of the fluorescence of the phenoxazinium duplexes ranges from $12 \%$ to $22 \%$ provided guanines are not placed in the vicinity of the phenoxazinium dye (Figure 3). The fluorescence is quenched significantly if a guanine is present as the counterbase or as part of the adjacent base pairs, or both. It is important to point out that this profile of emission properties is observed regardless of whether the chromophore has been attached to the 2'-position of uridine or as a non-nucleosidic DNA base surrogate using the acyclic glycol linker. In fact, the quantum yields of the corresponding duplex pairs are similar, e.g., DNA1A vs DNA2A.

Coumarin-Modified DNA. Due to this similarity that has been observed between the nucleosidic and non-nucleosidic approaches for phenoxazinium-modified DNA duplexes, we decided to incorporate the red coumarin label (azide 2 ) only to the 2 '-position of uridine. Those modified duplexes would show

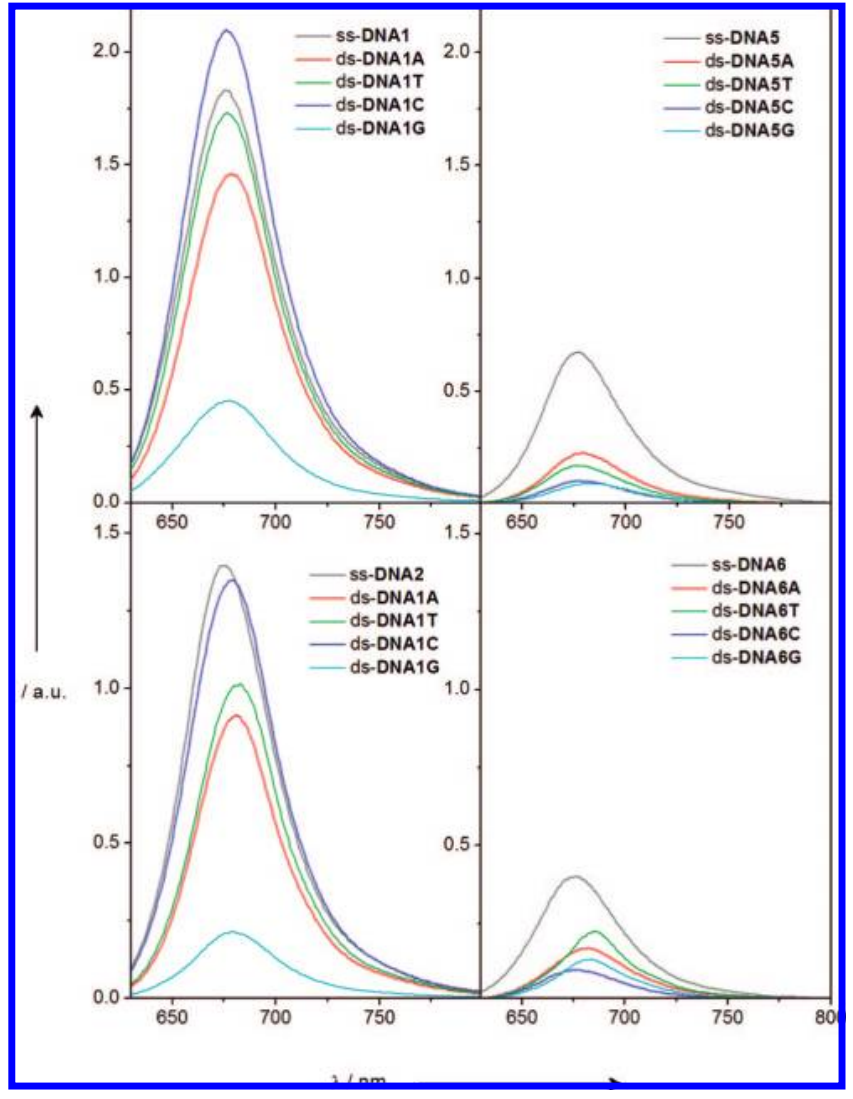

Figure 2. Fluorescence spectra of single-stranded DNA1, DNA2, DNA5, and DNA6 and the corresponding duplexes $(2.5 \mu \mathrm{M})$ in sodium phosphate buffer $(10 \mathrm{mM})$ of $\mathrm{pH} 7.0, \mathrm{NaCl}(250 \mathrm{mM}), \lambda_{\mathrm{exc}}=610 \mathrm{~nm}$.

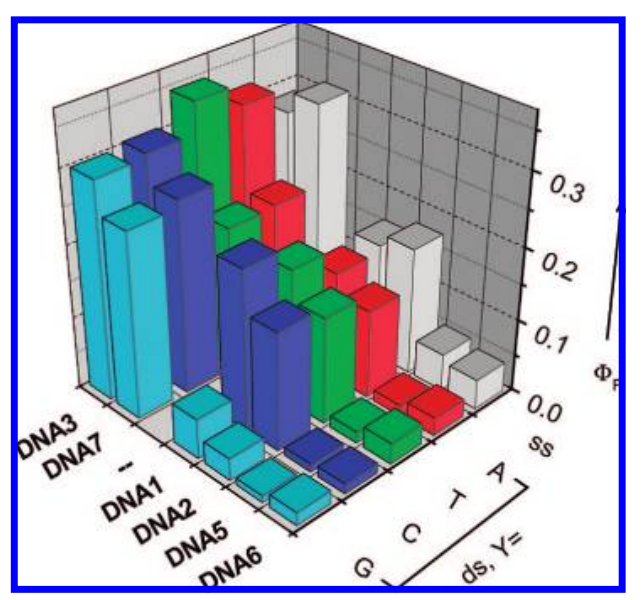

Figure 3. Graphical display of the quantum yields $\left(\Theta_{\mathrm{F}}\right)$ of the coumarinmodified DNA3 and DNA7 and the phenoxazinium-modified DNA1, DNA2, DNA5, and DNA6.

defined Watson-Crick base pairing and exhibit a similar thermal stability to that of the unmodified matched duplexes (DNA4A and DNA8A). Accordingly, we have prepared DNA3Y and DNA7Y that bear variations of the adjacent base pairs and the counterbase. The melting temperatures show two major trends that are similar to the phenoxazinium-modified DNA2Y and DNA6Y. (i) As expected, the coumarin-modified uridine clearly prefers the adenine opposite to the modification site. (ii) Compared to the corresponding matched and unmodified duplexes DNA4A and DNA8A, respectively, the thermal stabilities of the matched but modified duplexes are only slightly lower $\left(-0.5{ }^{\circ} \mathrm{C}\right.$ for DNA7A $)$ or even higher $\left(+1.0{ }^{\circ} \mathrm{C}\right.$ for 


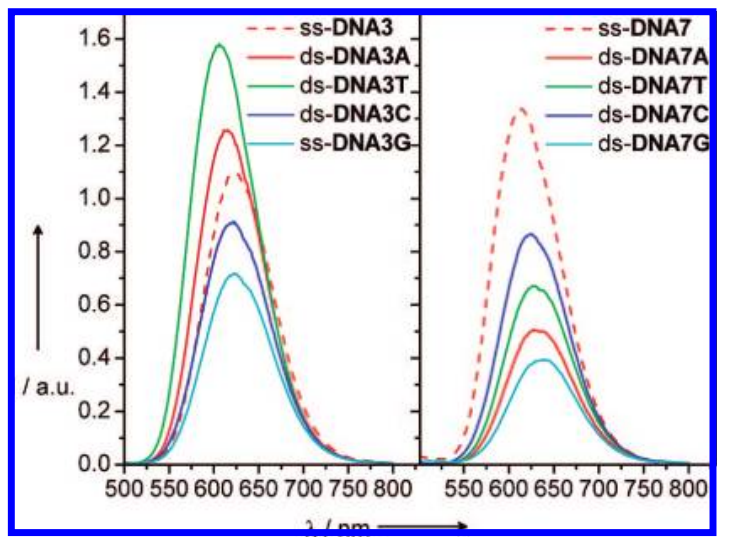

Figure 4. Fluorescence spectra of single-stranded DNA3 and DNA7 and the corresponding duplexes $(2.5 \mu \mathrm{M})$ in sodium phosphate buffer $(10 \mathrm{mM})$ of $\mathrm{pH} 7.0, \mathrm{NaCl}(250 \mathrm{mM}), \lambda_{\mathrm{exc}}=500 \mathrm{~nm}$.

DNA3A). (iii) The coumarin dye stabilizes mismatches in DNA3Y and DNA7Y (Y = T, C, G), but not to such an extent as that observed in the case of the corresponding phenoxazinium-modified duplexes.

The UV/vis spectra of the modified single strands and duplexes show an absorption maximum in the range between 515 and $534 \mathrm{~nm}$ (Supporting Information Figures S3, S6). It is interesting to note that the duplexes bearing guanine as the counterbase (DNA3G) or as the base adjacent to the coumarin modification site (DNA7Y) show the most red-shifted absorption, particularly significant in DNA7G (534 nm). The steadystate fluorescence spectra of the coumarin-modified duplexes display maxima in the range 606-637 $\mathrm{nm}$ (Figure 4). It is important to point out that all modified duplexes exhibit a significant Stokes' shift of approximately $100 \mathrm{~nm}$. The duplexes DNA3Y show quantum yields in the range between 30\% and $35 \%$. Compared to other coumarins, this is a very large Stokes' shift that is of particular interest with respect to potential fluorescence resonance energy transfer (FRET) studies. In fact, labels $\mathbf{1}$ and $\mathbf{2}$ form a well-matched FRET pair excitable with the argon ion laser. The quantum yields of the duplexes with adjacent G-C base pairs (DNA7Y) are lower (20-27\%); however, a nearly complete fluorescence quenching as in the case of the corresponding phenoxazinium-modified duplexes is not observed.

\section{DISCUSSION}

Both the blue phenoxazinium fluorophore of $\mathbf{1}$ and the red coumarin of $\mathbf{2}$ are unstable under the basic conditions typically applied for DNA workup. Using the appropriate phosphoramidites as DNA building blocks is therefore a difficult task for the incorporation of these dyes into oligonucleotides. Postsynthetic "click" chemistry, however, allowed the modification of presynthesized alkynylated oligonucleotides with the fluorescent azides $\mathbf{1}$ and $\mathbf{2}$ to prepare the corresponding modified duplexes DNA1Y-DNA3Y and DNA5Y-DNA7Y.

The most critical issue with respect to fluorescent labeling of nucleic acids is fluorescence quenching caused by charge transfer and oxidation of guanines (48). Accordingly, there is a major difference between the two fluorophores of $\mathbf{1}$ and $\mathbf{2}$ based on photophysical and electrochemical data in the literature. The oxidation potential of guanine is $\sim 1.3-1.4 \mathrm{~V}$ vs normal hydrogen electrode (NHE) (49). According to the Rehm-Weller equation, the energy of the singlet-singlet transition $E_{00}$ has to be added to the reduction potential $E_{\text {red }}$ in order to calculate the excited-state potential and the driving force of a potential charge transfer reaction. In the case of fluorophore 1, the excited-state potential is estimated to be $E^{*}{ }_{\text {red }}=2.2 \mathrm{eV}$ (vs NHE) using $E_{\text {red }}$
$=-0.26 \mathrm{~V}$ (vs decamethylferrocen), $E_{00}=1.88 \mathrm{eV}$, and a correction value of $+0.54 \mathrm{~V}$ (from decamethylferrocen to NHE reference) (50). The excited-state potential of fluorophore $\mathbf{2}$ is significantly lower and estimated to be $E^{*}{ }_{\text {red }}=1.5 \mathrm{eV}$ using $E_{\text {red }}=-1.27 \mathrm{~V}$ (vs Ferrocen), $E_{00}=2.16 \mathrm{eV}$ and a correction value of $+0.63 \mathrm{~V}$ (from ferrocen to NHE reference) (50). Conclusively, these values indicate that the phenoxazinium label $\mathbf{1}$ is capable of oxidizing guanines in the sequential neighborhood, whereas the coumarin label 2 represents a borderline case. Hence, we expected sequence-dependent fluorescence quenching of the phenoxazinium dye of azide $\mathbf{1}$, and it is important to point out that we decided to use this property as a sensitive tool to compare the electronic interactions of the phenoxazinium chromophore with the DNA base stack in order to evaluate the role of the modification type (nucleosidic vs non-nucleosidic).

Accordingly, azide 1 was incorporated into oligonucleotides either as a nucleotide modification at the 2 '-position of uridine (DNA2Y and DNA6Y) or as a non-nucleosidic base substitution (DNA1Y and DNA5Y). As expected based on the photophysical data given above, the emission is quenched significantly if a guanine is present as the counterbase, as part of the adjacent base pair, or both. In fact, the fluorescence of the phenoxazinium-modified single strands and duplexes has a quantum yield of $>6 \%$ only if guanines are not located in direct vicinity of the chromophore. Most importantly, the quantum yield profiles (Figure 3) of the two duplex sets with the nucleoside modification (DNA2Y and DNA6Y) are very similar in comparison to the duplexes with the non-nucleosidic modification (DNA1Y and DNA5Y). This is a remarkable result that shows that the optical properties of fluorescent DNA do not depend on whether the dye has been incorporated as a DNA base substitution or as a $2^{\prime}$-nucleoside modification. In both cases, the interactions of the phenoxazinium dye with the counterbase and the adjacent DNA base pairs seem to be electronically similar.

In contrast to the similarity of the fluorescence properties, the phenoxazinium-modified duplexes show different thermal stabilities with respect to the type of modification. Compared to the unmodified and matched duplexes DNA4A and DNA8A, the replacement of the $2^{\prime}$-deoxyribofuranoside by the nonnucleosidic glycol linker (DNA1A and DNA5A) result not only in the loss of a preferred base pairing but also in a decrease of thermal stability. Both effects have been expected on basis of the design of the two types of modification (nucleosidic vs nonnucleosidic). However, the second effect is not very pronounced and thus surprising. Typical for single glycol linker substitutions in DNA is a thermal destabilization of more than $10{ }^{\circ} \mathrm{C}$ (43, 46, 51). For the phenoxazinium-modified DNA1Y and DNA5Y, the values are significantly lower. Obviously, some of the lost thermal stability can be regained by the hydrophobic stacking interactions of the phenoxazinium chromophore, presumably intercalated. The stabilizing effects are highest especially in the presence of adjacent G-C base pairs (DNA5Y).

This interpretation is supported by the observation that the mismatched modified duplexes are more stable against thermal dehybridization compared to the corresponding mismatched but unmodified duplexes. This represents another remarkable result, since it indicates that the phenoxazinium dye, presumably intercalated, stabilizes single-base mismatches by its hydrophobic interactions. It is important to point out that, for this effect, similar to the fluorescence quenching, it does not matter whether the phenoxazinium dye has been incorporated as a nonnucleosidic DNA base substitute or as a 2'-nucleoside modification.

Taking together with the results of the phenoxaziniummodified duplexes, it becomes clear that the application of the 2 -modification site of uridine is preferred in comparison to the non-nucleosidic, glycol-assisted DNA base substitution. Hence, 
the red coumarin label 2 was attached only to the 2 -position of uridine. The steady-state fluorescence spectra of all coumarinmodified duplexes show a significant Stokes' shift of approximately $100 \mathrm{~nm}$ and quantum yields in the ranges $30-35 \%$ (DNA3Y) and 20-27\% (DNA7Y). In contrast to the phenoxazinium-modified duplexes, nearly quantitative fluorescence quenching by charge transfer to guanines is not observed here. The lower quantum yields in DNA7Y are accompanied by a red-shifted absorption of the coumarin label. Obviously, guanine strongly interacts with the coumarin in the ground state, which also affects the exciplex-type fluorescence originating from the excited state, most significantly observed in the case of DNA7G. Nevertheless, the coumarin represents a powerful label for fluorescent nucleic acids based on the Stokes' shift and the quantum yields.

\section{CONCLUSIONS}

The blue phenoxazinium azide $\mathbf{1}$ and the red coumarin azide 2 represent examples of two structurally different but novel types of fluorophores (35). A common feature of both dyes is the instability under strongly basic conditions that are typically used for DNA workup. Hence, both chromophores cannot be easily incorporated into DNA using the standard phosphoramidite building block chemistry. However, "click" chemistry allows the postsynthetic modification of oligonucleotides that were presynthesized and modified with an alkyne group. A range of DNA duplexes was modified with the blue phenoxazinium azide 1; one set of duplexes carried the chromophore attached at the $2^{\prime}$-position of uridine, and a second set contained the chromophore as a non-nucleosidic DNA base surrogate that has been inserted using an acyclic glycol linker. These phenoxaziniummodified duplexes were characterized by optical spectroscopy. A sequence-dependent fluorescence quenching of the phenoxazinium 1 was applied as a sensitive tool to compare the stacking interactions with respect to the structural variations (nucleosidic vs non-nucleosidic). Remarkably, the fluorescence properties do not depend on the modification site. It does not matter whether the chromophore has been attached to the $2^{\prime}$-position of uridine or as DNA base surrogate using the acyclic glycol linker. Thus, the application of the $2^{\prime}$-modification site of uridine is preferred in comparison to glycol-assisted DNA base surrogates. The $2^{\prime}$-chromophore-modified uridine still recognizes adenine as the counterbase and the duplexes do not exhibit a reduced thermal stability in comparison to the unmodified duplexes. Accordingly, the coumarin dye azide $\mathbf{2}$ was attached only using the nucleosidic approach that means by modification of the 2'-position of uridine. The significant Stokes' shift of $\sim 100 \mathrm{~nm}$ and the good quantum yields make the coumarin chromophore a powerful fluorescent label for nucleic acids in assays or cell biology. The postsynthetic "click" chemistry makes this dye now accessible to fluorescent labeling of nucleic acids.

\section{ACKNOWLEDGMENT}

This work was supported by the Deutsche Forschungsgemeinschaft, the Fonds der Chemischen Industrie, and the University of Regensburg. P.K. thanks the Alexander von Humboldt Foundation for a Humboldt fellowship (3.3-UNG/ 1126507).

Supporting Information Available: Absorption spectra of all modified DNA single strands and duplexes (Figure S1-S6); images of MS, ${ }^{1} \mathrm{H}$ NMR, and ${ }^{13} \mathrm{C}$ NMR for $5,{ }^{1} \mathrm{H}$ NMR and ${ }^{31} \mathrm{P}$ NMR for 6, HPLC analysis and MS of DNA1-3 and DNA5-7. This material is available free of charge via the Internet at http:// pubs.acs.org.

\section{LITERATURE CITED}

(1) Epstein, J. R., Biran, I., and Walt, D. R. (2002) Fluorescencebased nucleic acid detection and microarrays. Anal. Chim. Acta 469, 3-36.

(2) Johansson, M. K., and Cook, R. M. (2003) Intramolecular dimers: a new design strategy for fluorescence-quenched probes. Chem. Eur. J. 9, 3466-3471.

(3) Tan, W., Wang, K., and Drake, T. J. (2004) Molecular beacons. Curr. Opin. Chem. Biol. 8, 547-553.

(4) Ranasinghe, R. T., and Brown, T. (2005) Fluorescence bases strategies for genetic analysis. Chem. Commun. 5487-5502.

(5) Waggoner, A. (2006) Fluorescent labels for proteomics and genomics. Curr. Opin. Chem. Biol. 10, 62-66.

(6) Niemeyer, C. M., and Blohm, D. (1999) DNA microarrays. Angew. Chem. Int. Ed. Engl. 38, 2865-2869.

(7) Pirrung, M. C. (2002) How to make a DNA chip. Angew. Chem., Int. Ed. Engl. 41, 1276-1289.

(8) Tyagi, S., and Kramer, F. R. (1996) Molecular beacons: probes that fluoresce upon hybridization. Nat. Biotechnol. 14, 303-308.

(9) Heyduk, T., and Heyduk, E. (2002) Molecular beacons for detecting DNA binding proteins. Nat. Biotechnol. 20, 171-176.

(10) Strerath, M., and Marx, A. (2005) Genotyping-from genomic DNA to genotype in a single tube. Angew. Chem. Int. Ed. Engl. 44, 7842-7849.

(11) Socher, E., Jarikote, D. V., Knoll, A., Röglin, L., Burmeister, J., and Seitz, O. (2008) FIT probes: peptide nucleic acid probes with a fluorescent base surrogate enable real-time DNA quantification and single nucleotide polymorphism discovery. Anal. Biochem. 375, 318-330.

(12) Wagenknecht, H.-A. (2008) Fluorescent DNA base modifications and substitutes: multiple fluorophore labeling and the DETEQ concept. Ann. N.Y. Acad. Sci. 1130, 122-130.

(13) Wojczewski, C., Stolze, K., and Engels, J. W. (1999) Fluorescent oligonucleotides - versatile tools as probes and primers for DNA and RNA analysis. Synlett 1667-1678.

(14) Huisgen, R. (1962) 1,3-dipolar cycloaddition. Past and future. Angew. Chem., Int. Ed. 2, 565-598.

(15) Lewis, W. G., Green, L. G., Grynszpan, F., Radic, Z., Carlier, P. R., Taylor, P., Finn, M. G., and Sharpless, K. B. (2002) Click chemistry in situ: acetylcholinesterase as a reaction vessel for the selective assembly of a femtomolar inhibitor from an array of building blocks. Angew. Chem. Int. Ed. Engl. 41, 1053-1057.

(16) Beckmann, H. S. G., and Wittmann, V. (2007) One-pot procedure for diazo transfer and azide-alkyne cycloaddition: triazole linkages from amines. Org. Lett. 9, 1-4.

(17) Lutz, J.-F. (2007) 1,3-Dipolar cycloadditions of azides and alkynes: a universal ligation tool in polymer and materials science. Angew. Chem. Int. Ed. 46, 1018-1025.

(18) Agard, N. J., Baskin, J. M., Prescher, J. A., Lo, A., and Bertozzi, C. R. (2006) A comparative study of bioorthogonal reactions with azides. ACS Chem. Biol. 1, 644-648.

(19) Wolfbeis, O. S. (2007) The click reaction in the luminescent probing of metal ions, and its implications on biolabeling techniques. Angew. Chem. Int. Ed. 46, 2980-2982.

(20) Weisbrod, S. H., and Marx, A. Novel strategies for the sitespecific labelling of nucleic acids. Chem. Commun., DOI: 10.1039/b809528k.

(21) Gramlich, P. M. E., Wirges, C. T., Manetto, A., and Carell, T. Postsynthetic DNA modification through the copper-catalyzed azide-alkyne cycloaddition reaction. Angew. Chem. Int., Ed. DOI: 10.1002/anie.200802077.

(22) Seela, F., Sirivolu, V., and Chittepu, P. (2008) Modification of DNA with octadiynyl side chains: synthesis, base pairing, and formation of fluorescent coumarin dye conjugates of four nucleobases by the alkyne-azide "click" reaction. Bioconiugate Chem. 19, 211-224.

(23) Kocalka, P., Andersen, N. K., Jensen, F., and Nielsen, P. (2007) Synthesis of 5-(1,2,3-triazol-4-yl)-2'-deoxyuridines by a click chemistry approach: stacking of triazoles in the major 
groove gives increases nucleic acid stability. ChemBioChem 8 , 2106-2116.

(24) Kocalka, P., El-Sagheer, A. H., and Brown, T. (2008) Rapid and efficient DNA Strand cross-linking by click chemistry. ChemBioChem 9, 1280-1285.

(25) Geci, I., Filichev, V. V., and Pedersen, E. B. (2007) Stabilization of parallel triplexes by twisted intercalating nucleic acids (TINAs) incorporating 1,2,3-triazole units and prepared by microwave-accelerated click chemistry. Chem. Eur. J. 13, 63796386.

(26) Salic, A., and Mitchison, T. J. (2008) A chemical method for fast and sensitive detection of DNA synthesis in vivo. Proc. Natl. Acad. Sci. U.S.A. 105, 2415-2420.

(27) Jawalekar, A. M., Meeuwenoord, N., Cremers, J. S. G. O., Rutjes, F. P. J. T., and Delft, F. L. v. (2008) Conjugation of nucleosides and oligonucleotids by $[3+2]$ cycloaddition. J. Org. Chem. 73, 287-290.

(28) Link, A. J., Vink, M. K. S., and Tirrell, D. A. (2004) Presentation and detection of azide functionality in bacterial cell surface proteins. J. Am. Chem. Soc. 126, 10598-10602.

(29) Iida, S., Asakura, N., Tabata, K., Okura, I., and Kamachi, T. (2006) Incorporation of unnatural amino acids into cytochrome $c_{3}$ and specific viologen binding to the unnatural amino acid. ChemBioChem 7, 1853-1855.

(30) Humenik, M., Huang, Y., Wang, Y., and Sprinzl, M. (2007) $\mathrm{C}$-Terminal incorporation of bio-orthogonal azide groups into a protein-oligodeoxynucleotide conjugates by $\mathrm{Cu}^{\mathrm{I}}$-catalyzed cycloaddition. ChemBioChem 8, 1103-1106.

(31) Weisbrod, S. H., and Marx, A. (2007) A nucleoside triphosphate for site-specific labelling of DNA by the Staudinger 1;igation. Chem. Commun. 1828-1830.

(32) Gierlich, J., Burley, G. A., Gramlich, P. M. E., Hammond, D. M., and Carell, T. (2006) Click chemistry as a reliable method for the high-density postsynthetic functionalization of alkynemodified DNA. Org. Lett. 8, 3639-3642.

(33) Gramlich, P. M. E., Warncke, S., Gierlich, J., and Carell, T. (2008) Click-click-click: single to triple modification of DNA. Angew. Chem. Int. Ed. 47, 3442-3444.

(34) Gierlich, J., Gutsmiedl, K., Gramlich, P. M. E., Schmidt, A., Burley, G. A., and Carell, T. (2007) Synthesis of highly modified DNA by a combination of PCR with alkyne-bearing triphophates and click chemistry. Chem. Eur. J. 13, 9486-9494.

(35) Mader, H., Li, X., Saleh, S., Link, M., Kele, P., and Wolfbeis, O. S. (2008) Fluorescent silica nanoparticles. Ann. N.Y. Acad. Sci. 1130, 218-223.

(36) Kele, P., Mezo, G., Achatz, D., and Wolfbeis, O. S. (2008) Dual labeling of biomolecules by click chemistry: a sequential approach. Angew. Chem., Int. Ed. in press.

(37) Grotli, M., Douglas, M., Eritja, R., and Sproat, B. S. (1998) 2'-O-Propargyl oligoribonucleotides: synthesis and hybridisation. Tetrahedron 54, 5899-5914.
(38) Zhang, L., Peritz, A. E., Carroll, P. J., and Meggers, E. (2006) Synthesis of glycol nucleic acids. Synthesis 645-653.

(39) Schlegel, M. L., Essen, L.-O., and Meggers, E. (2008) Duplex structure of a minimal nucleic acid. J. Am. Chem. Soc. 130, 81588159.

(40) Filichev, V. V., Christensen, U. B., Pedersen, E. B., Babu, B. R., and Wengel, J. (2004) Locked nucleic acids and intercalating nucleic acids in the design of easily denaturing nucleic acids: thermal stability studies. ChemBioChem 5, 1673-1679.

(41) Huber, R., Amann, N., and Wagenknecht, H.-A. (2004) Synthesis of DNA with phenanthridinium as an artificial DNA base. J. Org. Chem. 69, 744-751.

(42) Amann, N., Huber, R., and Wagenknecht, H.-A. (2004) Phenanthridinium as an artificial base and charge donor in DNA. Angew. Chem. Int. Ed. Engl. 43, 1845-1847.

(43) Wanninger, C., and Wagenknecht, H.-A. (2006) Indole as an artificial DNA base incorporated via an acyclic DNA base surrogate. Synlett 2051-1054.

(44) Wagner, C., and Wagenknecht, H.-A. (2006) Perylene-3,4: 9,10-tetracarboxylic acid bisimide dye as an artificial DNA base surrogate. Org. Lett. 8, 4191-4194.

(45) Baumstark, D., and Wagenknecht, H.-A. (2008) Perylene bisimide dimers as fluorescent glue for DNA and for base mismatch detection. Angew. Chem. Int. Ed. 47, 2652-2654.

(46) Wagner, C., and Wagenknecht, H.-A. (2008) Phenothiazine as a redox-active DNA base substitute: comparison with phenothiazine-modified uridine. Org. Biomol. Chem. 6, 48-50.

(47) Menacher, F., Rubner, M., Berndl, S., and Wagenknecht, H.A. (2008) Thiazole orange and Cy3: improvement of fluorescent DNA probes using short range electron transfer. J. Org. Chem. 73, 4263-4266.

(48) Kurata, S., Kanagawa, T., Yamada, K., Torimura, M., Yokomaku, T., Kamagata, Y., and Kurane, R. (2001) Fluorescent quenching-based quantitative detection of specific DNA/RNA using a BODIPY FL-labeled probe or primer. Nucleic Acids Res. 29, e34.

(49) Steenken, S., Jovanovic, S. V., Candeias, L. P., and Reynisson, J. (2001) Is "Frank" DNA-strand breakage via the guanine radical thermodynamically and sterically possible. Chem. Eur. J. 7, 2829-2833.

(50) Pavlishchuk, V. V., and Addison, A. W. (2000) Conversion constants for redox potentials measured versus different reference electrodes in acetonitrile solutions at $25^{\circ} \mathrm{C}$. Inorg. Chim. Acta 298, 97-102.

(51) Schlegel, M. K., Peritz, A. E., Kittigowittana, K., Zhang, L., and Meggers, E. (2007) Duplex formation of the simplified nucleic acid GNA. ChemBioChem 8, 927-932.

BC8004864 